\title{
Two Travellers in Europe. An Early-Nineteenth-Century Panorama
}

Technológiai utazás a modern kor hajnalán: Válogatás Gerics Pál és

Lehrmann József georgikoni professzorok nyugat-európai jelentéseiből és naplóiból (1820-1825). Edited by György Kurucz.

Budapest: Károli Gáspár University of the Reformed Church in Hungary L'Harmattan Publishing, 2020. 744 pp.

"Kedves Hazámfiai, mozdulni kell...": Georgikoni peregrinatio oeconomica a 19. század elején. By György Kurucz.

Budapest: Corvina Publishing - Ráday Collection Budapest, 2020. 303 pp.

\section{Gábor Alföldy}

Institute of Art History, Research Centre for the Humanities, ELKH, 1453 Budapest, P.O.B. 33, Hungary; alfoldyg@gmail.com

Two books, a monograph and a compilation of primary source texts by György Kurucz were published last year. Their topic is the same: one can follow two young men in their 'technological' journeys across most of Europe. Through the primary texts we may gain insight into the stops on their journey, which reached the most diverse places on the continent, as well as in Great Britain. The monograph presents the latter from an external point of view, simultaneously analyzing and commenting on the observations of the two characters and placing them into the context of the history of science.

Historian György Kurucz (professor and vice-rector of the Károli Gáspár University of the Reformed Church in Hungary, Budapest) has been deeply involved in dealing with the activities of the Festetics family who played a preeminent role in Hungarian cultural history. First, he directed his attention to the Georgikon school of agriculture at Keszthely-the first European agricultural institution to operate at the level of tertiary education -, and later to the efforts of the founder of Georgikon, Count György Festetics, to organize and modernize his estates. Kurucz has raised completely new questions in a long-researched field. Based on his thorough archival research and knowledge of international literature, he has drawn attention to unknown facts and uninvestigated connections. Having written a grand monograph 
about the count, his attention now focused on the count's son, László. His fundamental conclusion is that the widespread and simplistic judgement of Count László Festetics as someone who in his attempt to manage assets squandered them and increased his debt to the point of bankruptcy is not sound. Instead, he was a "sapient and active" aristocrat who followed his father's footsteps and tried to modernize and improve conditions for agriculture on his estates and in his college of farming (Georgikon) in a versatile way. He knew that increasing production, improving quality, and selling produce more efficiently were essential factors, and that in order to achieve this, besides having highly skilled employees and teaching staff, knowing about and implementing world-class methods was necessary. In order to achieve his goals he singled out two intelligent young professionals who navigated comfortably in society. One of them was Pál Gerics, a physician and veterinarian; the other the horticulturist and viticulturist József (Joseph) Lehrmann. They were sent on an almost five-year journey across Europe.

The two volumes, published on the $200^{\text {th }}$ anniversary of their departure, see their journeys through. It is conceivable that the journey of the two young men was planned by Count György Festetics (d. 1819), but the detailed itinerary was certainly elaborated by László, his son. Not only were the stops on the itinerary and locations to be visited defined in the detailed instructions, but also the persons with whom to become acquainted, and the fields the travelers were to familiarize themselves with. The purpose of the peregrinatio oeconomica of the two young professionals-sometimes accomplished together, sometimes separately-was to serve the development of the homeland (Hungary), beyond collecting and transferring directly utilizable knowledge to the Festetics estates and the Georgikon school. After returning, both professionals became professors at Georgikon. Gerics was later awarded the office of archon (provost), and became a member of the Directio of the estates.

The count's approach of sending his employees on multiannual study tours was typical of Europe's enlightened monarchs and aristocrats. Such a method of obtaining knowledge was the accepted method of enhancing the circulation of the knowledge of that age, as pointed out by Kurucz in his introductory chapter. It should be noted that Count György Festetics had already sent his employees on similar journeys-for example, his horticulturist, Gergely Bene. In first place, both György and László Festetics attempted to select professionals with experience from Göttingen or other foreign centers of knowledge for the teaching staff of Georgikon.

The two books, published by two different publishers and in different formats, masterfully complement one another. The source collection prepared by Kurucz, besides the instructions of the count, includes the diaries of the two travelers that detail their observations, and a series of accounts sent to the Directio at Keszthely complemented by the summary reports of Gerics and Lehrmann (re)written in 
hindsight. While Gerics noted down his observations in Hungarian, Lehrmann did so in German. Of the two, Gerics's accounts are especially thrilling due to his extensive interests, clear understanding of problems, and colloquies with high-ranking or admittedly best-in-profession personalities. His fluent style makes these accounts extraordinarily readable. His hosts often shared with him otherwise professionally undisclosed pieces of information. Lehrmann's scope of interest was narrower. $\mathrm{He}$ moved mostly among the disciplines of horticulture and viticulture, and included a multitude of valuable information related to these areas. A recurring element of the accounts of both is descriptions of flower gardens, parks, horticultural firms, and botanical gardens, which forms a valuable layer of the original text. Just like Lehrmann, Gerics was also at home with botany, an interest common among physicians at the time. Furthermore, we come to know him through his writings as a highly erudite intellectual in other fields, too.

The scope of experience obtained and delivered in writing encompasses innumerable fields of science and culture, and is so wide and so inexhaustibly rich that international researchers of such may also significantly benefit from it. The flood of information regularly sent via mail to Keszthely was in many ways utilizable for the Directio that was managing the Festetics estates, and for the Georgikon agricultural school, too. Models, sketches, engravings, and packages of books complemented the letters. (The package from Paris, for example, included 49 books, four technological illustrations, five models of tools, and an additional 12 medical and veterinary aids.) Lamentably, the bankruptcy of the Festetics estates that occurred only a few years later made it impossible to actively utilize the majority of the knowledge that had been obtained. In the still functioning Georgikon, however, the transfer of knowledge from the observations was accomplished for decades to come. In retrospect, the manuscript written by Gerics is evidence of his intention of publishing it. Therefore, he also perceived the significance of obtaining knowledge and making observations correctly.

One subject of the journey that encompassed many areas, labelled by László Festetics as outstandingly important, was obtaining information on sheep farming and how to promote the direct sale of wool. Wool was a question of life or death in those times, as it were, since wool production was practically the only secure and significant source of income of major Hungarian landowners in the 1820s. Its sale, however, was only possible under quite disadvantageous conditions defined by intermediary merchants. Gerics was assigned the task of becoming oriented about the potential sales of Hungarian wool to the merchants and wool factories of the countries that were visited. Experiences in this field were distressing, and are a good example of the state of affairs of Hungarian trade at the time. High quality Hungarian wool was remarketed as German or even British. "Hungarian" wool, on 
the other hand, was identified as dirty and unsorted, and was left out of consideration. Gerics gave advice for promoting the direct sale of wool-for example, he recommended sending agents to the English market.

Besides fulfilling their previously determined tasks of describing their visits, the diaries and accounts of the two young travelers also give us the opportunity to gain insight into their personal observations, opinions, and experiences. Although their personalities remain in the background because of the genre and point of view of the 'employee reports', we still get to know about their particular living conditions and hardships. Gerics noted down in Stuttgart that he had even been able to see six codices of King Mathias' Bibliotheca Corviniana, and in Bologna he had had a discussion with Cardinal Mezzofanti in Hungarian.

In order to achieve the goals of these study trips, which were extensive both geographically and in terms of their subjects, it was necessary for the two young men to obtain a multitude of letters of introduction. They were furnished with these not only by their commissioner, Count László Festetics, via his network of connections (partly due to the fact that his wife was a Hohenzollern princess), but Gerics and Lehrmann themselves also used their new acquaintances to request further letters of introduction, whenever possible. This was the only way to gain admittance to a great many places-and in turn, they were received in the most amicable manner.

These letters of introduction not only made entry possible to the residences of the high nobility, estates, factories, the collections of academic departments, laboratories, and wine cellars, but also helped them to be taken into confidence by the owners, managers, professors, and scientific circles who welcomed them in the locations and institutions they visited. Thus they were able to participate in events as esteemed guests that could normally only be visited by insiders. Additionally, information was shared with them that otherwise would not have been available to them, either in the literature or anywhere else. The essence of technological journeys is autopsia: getting to experience the theory in the literature in practice; and, if necessary, finding contradictions, posing questions on the spot, and having the opportunity to discuss them. On many occasions, their hosts were also eager to know the opinions and observations of our travelers. Autopsia was of decisive importance in the case of the visits to universities, since the travelers (mostly Gerics) were able to participate in human and animal autopsies and witness pioneering experiments, as well as consult inventors in person. The travelers could familiarize themselves with the latest sowing machines, as well as the then newly invented stethoscope.

The famous French vineyards with their viticulture and viniculture made a lasting impression on Lehrmann, but he also found it important to record a modern greenhouse in a drawing and mail it to the Directio. He was at liberty to meet leading botanists and head gardeners of gardens of the era (for example, the Thouin brothers of Paris). 
Consequently, besides the diversity of locations, one may get to know about the magnates of Europe, experimental model farmers, world-renowned scientists, bankers, and a series of other interesting personalities while reading the texts.

On the cover of this extensive publication, Kurucz modestly lists himself as "editor" of the detailed records provided by the two travelers, albeit it was he who wrote the voluminous introductory treatise and selected and published the ably chosen excerpts from the vast source text. Additionally, it was he who transcribed the entirety of the vast text material written in Hungarian and in German gothic script that he personally researched in various collections (in the National Archives of Hungary, and in the Manuscript Collection in the National Széchényi Library). He also supplied the text with numerous annotations and a list of names of referenced persons for identification, in addition to preparing an extensive index of proper names. Perhaps the only question one is left with concerns the following shortcoming: "Why is this tremendous amount of work not even referred to in a single linel?"

Kurucz begins both volumes with an introductory treatise. He provides comprehensive perspective about the background of the documents in both: on the one hand, he describes the aspirations of Counts György and László Festetics, and on the other the economic literature, its arborescent interactions and effects, and also the acquisition of technical books for Georgikon.

The monograph volume is a rather differentiated and multidisciplinary elaboration of the topic. The author starts from a distance, summarizing the educational/ organizational activities of György Festetics. In relation to the educational strategy of Georgikon in Keszthely, and the enlargement of the estate library (the Helikon Library today), which serves as a model for adaptation, we are given a survey of the extraordinarily rich book collection of economic literature of the era. Thus we are introduced to a cross-section of the international (mostly English and German) economic literature of the time. Naturally, the central part of the volume comprises a description and analysis of the journey, and its examination from different perspectives.

The volume of original texts forms part of the primary source publication series of the Károli Gáspár University of the Reformed Church of Hungary, and its stated aim is to fill a gap in education. It is all the more suitable for this purpose, since we have not been able to read a similarly thorough and versatile travelogue and scientific overview by Hungarian authors from the respective decades thus far. The descriptions selected by Kurucz are rather economical: they are informative, yet not lengthy. (Kurucz has edited out some redundant sections, though.) In his introductory treatise, the analysis of the peregrinatio oeconomica is not omitted either.

While the source publication volume does not include figures, the monograph is exceptionally ambitious with its high-quality layout. The multifaceted observations about the genre of technological journeys and the internalization of culture 
as a whole are highlighted by a multitude of (approximately) contemporary engravings: townscapes, country houses, factories, and figures depicting snapshots of life from university education to social milieu.

Thanks to the work of Kurucz, we can now draw on this gigantic mass of information at our liking. The appreciative accounts of the two young travelers and their objective professional descriptions and subjective comments will be extremely useful for foreign researchers as well. In the monograph, one may find reference to descriptions omitted from the primary text volume for reasons of brevity, since the main text practically provides a complete summary of the journey of the two young travelers. Thus one may search for any of the places and subjects that were visited, as we are informed about the content and nature of the descriptions via short mentions.

These two volumes are a treasure trove for domestic and international researchers. The precise and detailed indices compiled by Kurucz help the reader find the details they are most interested in. Nevertheless, once readers hold the book in their hands, they will not be satisfied with this much: the text will inspire further exploration. Should one wish to get to know, 'on foot', the Europe of the decade following Napoleon, it can be done by reading through these two volumes. 